\title{
Deficiencies and Countermeasures of Financial Indicators in Enterprise Performance Evaluation
}

\author{
Yanli Li \\ Management Department \\ Guilin University of Technology, GLUT \\ Guilin, China
}

\begin{abstract}
In enterprise performance evaluation, the rationality of the selection of financial indicators has an important influence on the evaluation result. The paper analyzes the financial indicators used in current financial evaluation, finds its existing problems, and proposes that enterprises can gradually improve performance evaluation system of enterprises by introducing cash flow indicator, non-financial indicator, using EVA indicator and other methods, to provide efficient bas is of decision the ories for enterprise managers.
\end{abstract}

Keywords-performance evaluation; financial indicator; cash flow; EVA growth rate

\section{INTRODUCTION}

Performance evaluation is both the basis of enterprise remuneration mechanism and the important basis for enterprises to improve business management and increase economic returns, playing an irreplaceable role in enterprise management. As an important content of enterprise performance evaluation, financial indicator has played a supporting and guaranteeing role to provide financial analysis data, make scientific decisions, grasp the right direction of enterprise development, maximize economic benefits for enterprise decision makers. With continuous development of commodity economy and perfection of accounting standards, the inherent vice of the financial indicator used for performance evaluation has been shown day by day, affecting correct interpretations and decisions of business stakeholders. Thus, it appears to be particular important to improve and perfect financial indicator in enterprise performance evaluation.

\section{DEFECT IN EVALUATION INDICATORS OF SOLVENCY}

Good solvency can not only reduce financial risks, but it is also of great significance to continuous operation of enterprise, protection of creditor's interests and confidence of investors. The current evaluation indicators of solvency have the following defects.

\section{A. Have neglected the use of cash flow information}

Nowadays, users of information are paying more and more attention to the information reflected in chart of cash flow as modern enterprise develops. However, indicators in current enterprise performance evaluation system reflect serious lack of cash flow indicators. ${ }^{[1]}$ Traditional indicators can't evaluate solvency of enterprise and quality of earnings objectively any more. Cash is a strong guarantee for enterprises to repay their debts. In practice, many enterprises fall into business difficulties that the financial situation is deteriorating and are even bankrupt, although they have paper profits. In fact, solvency calculated according to balance sheet has a great uncertainty, which is a result of accounting based on accrual system. In other words, a profitable enterprise may not have enough cash flow which will reduce the actual solvency and payment ability of the enterprise in the future. For repayment of debt, cash flow is the essential element that determining rise and fall or life and death of enterprises and reflecting enterprises' nature. Thus, it is necessary to establish indicators to reflect cash flow information.

\section{B. Possibility of whitewashing indicators}

Because most users of information evaluate financial conditions and operating results of enterprises according to annual financial statements on enterprises, enterprises will exaggerate the current assets in enterprise annual reports by arranging receivables timidly, reducing provisions for bad debt and other means at the end of the year to make flow ratio value seem more consistent with standard values and show solvency of enterprises falsely. Besides, enterprises can also reduce current liabilities and whitewash short-term solvency indicators factitiously by repaying debts temporarily at the end of year to mislead users of information. If the enterprise performance evaluation is mainly built on the financial indicators of annual report, enterprise managers will be encouraged or driven to manipulate financial indicators factitiously by whitewashing economic work to get good performance evaluation.

\section{Hysteretic nature of static indicators}

All indicators of current solvency appraisal system are mainly calculated according to the data on balance sheet of enterprises. Data on balance sheet reflects timing indicators which show the financial condition of the enterprise in a certain day and a solidified static inventory concept. However, liquidation of assets and repayment of debts are dynamic flow concepts because they are in a constantly changing process all the time. So, hysteretic nature and deviation of analysis result are inevitable when evaluating liquidation and dynamic solvency of accounts by using pure static indicators and leading to faulty evaluations of users of information as a result. Thus, should fully consider the relationship between static indicators and dynamic liquidation and establish an objective solvency analysis system in current solvency analysis system. 


\section{Haven't considered the strength and weakness of solvency}

Asset-liability ratio reflects guarantee extend of assets to equity of enterprise creditors. Total assets mentioned in the denominator of the formula include all assets of the enterprise. But not all assets can be material guarantee for repayment, because bad assets, fictitious assets and assets that are mispriced can affect the authenticity of indicators, and there is a great uncertainty whether the intangible assets of enterprises can be guarantees of repayment of debt. Thus, it is imperative to improve indicators of asset-liability ratio to reflect the longterm solvency of enterprise objectively. Total assets used to repay debt should only refer to realizable assets to guarantee the accuracy of evaluation of enterprise solvency.

\section{DEFECT IN EVALUATION INDICATORS OF PROFITABILITY}

Enterprise profitability refers to enterprise's ability to get profits continuously, maintain the long-term survival and development in market competition by using available resources. The ability of enterprises to obtain profits is directly related to the continuous operation of enterprises. The current evaluation indicators of profitability have the following defects.

\section{A. Can't reflect profit quality of enterprises comprehensively}

The current enterprise profitability indicators are mostly evaluated from the aspect of profitability. Profits are calculated and evaluated based on accrual system. ${ }^{[2]}$ This kind of profit is just book profit but not cash profit enterprises have obtained. When sales revenues realized by enterprises are realized by receivables or the amount of receivables is large and receivables recovery ability is weak, enterprise profitability can't be said to be strong even if the profitability indicators are high. When receivables of enterprises have a large amount of bad debts in the following year of the evaluation period, it is meaningless no matter how high the profitability indicators are in the evaluation period. It is hard to give an objective evaluation of enterprise profitability 'quality' because of the difficult realization of cash profits. Only when introducing indicators reflecting cash profits in evaluation indicator, can we understand the actual operating conditions of the enterprise.

\section{B. Possible earnings management}

The calculation result of accounting profit is always hard to reflect the actual profitability and earnings quality of enterprises because it is greatly influenced by human factors. And the separation of management right and ownership inevitably leads to information asymmetry between managers and owners of enterprises, because there is a fundamental conflict between their interests. In the circumstance, the management may manipulate report information and manage earnings results to make earnings results meet the needs of short-term performance evaluation. As a result, the objectivity of performance evaluation results are affected.

\section{The lack of non-financial indicators}

The current profitability analysis system only evaluate the performance of enterprises by reflecting relevant ratio indicators of operating results profits on the basis of financial report. It has neglected that the financial report doesn't fully reflected the analysis indicators of non-financial factors, such as customer and employee satisfaction, strategic objectives of enterprises, market share, enterprise innovation ability and other aspects. These non-financial factors not only affect the profitability of enterprises, but also affect sustainable development of enterprises. For modern enterprises, high value market share and customer satisfaction are key indicators to measure the profitability of enterprises. Investors and creditors can analyze enterprise management ability according to changes in values to make investment decisions. Thus, enterprise performance evaluation should pay attention to the organic combination of financial indicators and non-financial indicators to fully reflect the profitability of enterprises.

\section{DEFECT IN EVALUATION INDICATORS OF OPERATING CAPACITY}

Operating capacity mainly shows the turnover efficiency of enterprise assets. The higher of turnover efficiency of each asset, the stronger the enterprise's operating capacity is. The current evaluation indicators of operating capacity have the following defects.

\section{A. Lack the evaluation of efficiency of intangible assets}

The current operating capacity evaluation system hasn't considered the analysis of effect of intangible assets, such as trademark right, goodwill, proprietary technology and other intangible assets of enterprises, which are important wealth obtained by enterprises in daily operation and important aspects to measure operating capacity of enterprises. However, due to the difficulty in pricing and uncertainty of research results, the research and development expenses of enterprises are mostly only recorded in profit and loss by ways of expenses and can't be shown in balance sheet, so they are always neglected by financial analysts. The amount of money enterprises invest in research and development expenses, the quantity of intangible assets all have an impact on enhancing the innovation ability of enterprises, and innovation is an important aspect of driving sustainable development of enterprises. So when evaluating operating capacity of enterprise assets, should pay equal attention to fixed assets and intangible assets and fully reflect operating capacity of enterprises, help users of information evaluate enterprise value accurately to prevent them from making short-term behaviors.

\section{B. Operating costs lack comprehensiveness}

Inventory turnover ratio of enterprises is the ratio of operating costs to average inventory balance within a period of time. But operating costs can't show the complete inventory turnover of enterprises within a certain accounting period, such as the businesses of debt payment in inventory in the process of enterprise debt restructuring, collection of inventory for construction in process, pay non-cash dividends to shareholders on inventory, issuing inventory to enterprise employees and non-currency trades conducted by enterprises with inventory. The above businesses are all related to inventory flow of enterprises but can't be shown in operating costs. This shows that calculating total inventory turnover of enterprises at operating costs will generally underestimate turnover speed of inventory, mislead users of information on decisions on 
inventory efficiency, and even may hamper the normal production and operation of enterprises.

\section{Haven't considered accounts receivable aging}

The turnover rate of receivables is an evaluation of operation efficiency of enterprises' receivables. If the turnover rate of enterprise receivables is higher, it indicates that the recovery of receivables is better. But if receivables of an enterprise are few and the aging time is longer, the turnover rate of receivables calculated in this way may be higher but it can't show the recovery situation of enterprise receivables is better. A large number of receivables where bad debts are likely to occur are even concealed in the higher turnover rate of receivables. Thus, users of information may be misled into making wrong decisions only according to turnover indicators of receivables.

\section{DEFECTS IN EVAluATION INDICATORS OF DEVELOPMENT ABILITY}

The evaluation of enterprise development ability can make operators or managers pay attention to sustainable operation of enterprise, continuously strengthen economic power and competitiveness of enterprises. The current evaluation indicators of development ability have the following defects.

\section{A. Don't reflect the sustainable development ability of enterprises}

Indicators used to evaluate development ability of enterprises only consider realization of enterprise operating objectives and the problem of capital preservation and appreciation, but don't consider the social, economic, environmental objectives related to business operation. ${ }^{[3]}$ Today's environmental problem has become a barrier to social progress and an important aspect affecting enterprise sustainable development. If just pay attention to enterprise profit and neglect requirements of other stakeholders, it will be bad for requirements for different information of evaluate subjects and will hinder the evaluation of enterprises' social responsibilities. Enterprises may take lots of short-term actions which are bad for their long-term development. Besides, innovation is the driving force of enterprise sustainable development. There are few indicators in the current enterprise performance evaluation system reflecting enterprise innovation ability. This also affects the evaluation of enterprise sustainable development ability.

\section{B. Can't show the connotation of enterprise development}

The connotation of enterprise development is the increase of value. However, enterprise value is by no means a simple sum of book value of tangible assets and intangible assets, but is the value determined by the contribution of total assets to the enterprise as a whole which can reflect the potential or expected profitability of enterprises. The current measurable indicators only pay attention to survey of peripheral value. Some enterprises realize an exponential growth of asset size, that is to say the sharp increase in total assets growth rate in the short term through the rapid expansion of asset size. However, the expansion won't be meaningful until the expansion of scale is supported by income increase. If only pay attention to the expansion of total assets but not to the quality of expansion, enterprises will be caught in the mire of mindless investment. Besides, the increase of sales income doesn't mean enterprise development ability is strengthened. If earnings quality is bad and cash flow is deficient, no matter how high the main business growth rate is, it is just a superficial phenomenon.

\section{SUGGESTIONS FOR IMPROVING FINANCIAL EVALUATION INDICATORS}

\section{A. Introducing cash flow indicators}

\section{1) Introducing cash maturity debt ratio}

For enterprises, sufficient cash flow is a strong guarantee for repaying due debts. Evaluating debt paying ability on the basis of cash flow is more authoritative. Use cash maturity debt ratio indicator to reflect the ability of an enterprise to pay its due debts with cash flow. The calculation formula is as follows.

Cash maturity debt ratio $=$ net cash flow $\div$ (current bill payable + long-term debt due in the current period)

The indicator can be used to reflect whether an enterprise has an ability to repay debt due in the current period with enough cash. The indicator is the ratio of the total cash flow of the enterprise's operation to the total amount of current debts and notes payable due in this period. It is an important complement of current ratio and quick-frozen ratio for it can eliminate influences of slack receivables, arrear inventory and other factors in current assets. Generally speaking, the enterprise's long-term liabilities due in the current period and notes payable can't be postponed and should pay back the exact amount when they are due. So they can better reflect the solvency of enterprises.

\section{2) Introducing net cash flow per share indicator}

Net operating cash flow per share indicator should be introduced because there is a possibility of human manipulation in the current profitability indicators and they can't fully reflect the defects in enterprise income quality. The indicator is the ratio of cash flow from business activities to the number of common shares issued by enterprises, reflecting the cash net flow each common share can obtain from business activities, revealing maximum cash dividend capacity can be obtained by each common share of a enterprise shareholder on the premise of keeping the initial cash stock. The calculation formula is as follows:

Net operating cash flow per share=net cash flow of business activities $\div$ total number of common shares issued outside

Net cash flow from business activities is the main source of enterprise cash dividend. So the indicator can visually reflect the quality of dividend payment capacity of enterprises. The higher the ratio is, the more cash dividend the shareholders gained in short-term year, the higher profit quality of each share. Otherwise, it shows the less net cash flow each common share earned, the worse the cash payment ability of enterprise share is. 


\section{B. Improve part of the financial indicators}

1) Improvement of inventory turnover indicators

For an enterprise with zero gross profit margins, inventory turnover is only a book value even if it is high. Inventory turnover is meaningful only when the enterprise makes profits. So enterprises should consider inventory turnover efficiency by combining profitability. Suggest introducing profit indicators of each turnover showing profit of each inventory turnover of enterprises.

Profit of each turnover=(business income-operating costsbusiness tax and surcharges) $\div$ turnover

If the profit of a turnover is positive number, it shows the enterprise has operating profit and inventory turnover is meaningful at the moment. The higher the indicator is, the higher the enterprise operating profit is. If the profit of the turnover is zero, it means the business income of the enterprise is equal to operating costs. That is, the business live beyond income and enterprises should take corresponding measures. If the profit of the turnover is negative number, it is meaningless no matter how high the inventory turnover is.

\section{2) Improvement of asset-liability ratio indicator}

Not all assets have the material guarantee to repay the debt. Total assets shall refer to realizable assets. If bad assets or unreal assets are contained, the evaluation result of indicators won't be accurate. And total liabilities and fictitious liabilities will affect the book value of total liabilities and lead to the distort of asset-liability ratio. On account of this, suggest improving the account form of asset-liability ratio indicators.

Improved asset-liability ratio=(total liabilities-estimated liabilities $) \div$ (total liabilities-long-term unamortized expensesdeferred tax assets-other assets that can't be realized)

The result more truly reflects the degree of guarantee of enterprise assets to liabilities by eliminating the influences of assets with inaccurate measurement and liabilities on indicators of enterprise solvency.

\section{Introducing non-financial information indicators}

The current financial analysis system reveals little nonfinancial information beyond the financial statements. The financial indicators selected for performance evaluation are all results of accounting numerical calculation. If the enterprise wants better development, it isn't enough to only focus on the data on enterprise reports. Analysis of non-financial information neglecting long-term development of enterprises won't be able to reflect the production and operation of enterprises as a whole. Thus, in order to offset the defect in the current financial analysis system, it is very necessary to introduce current non-financial measures.[4]

\section{1) Customer satisfaction}

Customer satisfaction refers to customer's evaluation of products or services provided by enterprises. The purpose of enterprise production and operation is to obtain maximum profit, to enable it to continuously develop and grow. And the primary task of profit and development is selling products or services produced by enterprises. An important factor got the survival and development of an enterprise is whether its products are accepted by the market and satisfy customers. The only way for an enterprise to gain lasting vitality is for its products to be recognized by customers. Customer satisfaction is the foundation of enterprise's survival. Thus, customer satisfaction should be incorporated into evaluation indicator system when conducting financial analysis.

\section{2) Human resources}

Human resources refer to all the talents embodied in the employees of the enterprise, including creative skills, professional abilities, executive abilities of employees of the enterprise and coordination abilities of managers. Nowadays, as knowledge economy leads the social trend, talent is the primary strategic resource for enterprise development and talent competition has become the most intense competition in contemporary enterprises. The lasting vitality of an enterprise can be truly reflected when measurement indicators of nonfinancial factors used to measure research and development personnel, creative talent are introduced.

\section{3) Innovation ability}

Innovation ability refers to the ability to utilize the existing resources of the enterprise, break the conventional thinking, suggest improvements or create new things in various fields of practical activities for some idealized needs or social needs. Nowadays, as science and technology develop rapidly, innovative consciousness and innovation ability have become key indicators of measuring a country's international competitiveness and determining international status. Statistics show that among the enterprises with rapid growth in global performance, most devote themselves to improving innovation ability and looking for breakthrough point of management mode in innovative development path, in order to realize the strategic goal of rapid growth of enterprise performance. The competition of modern society is competition for human creativity rather than talent competition. Thus, the current performance evaluation system should fully consider enterprise innovation ability and other non-financial indicators.

\section{Introducing EVA growth rate}

EVA is the English abbreviation of Economic Value Added. EVA has considered cost of common equity as a comprehensive financial management system. As a strategic management of the company, it guides the daily business decisions, investment and operation of projects of the enterprise, affects the construction of enterprise culture and ultimate wealth creation. The form of measurement is $E V A=$ after-tax operating profit-cost of capital. The growth rate of EVA refers to growth degree of EVA. That is, growth degree of ability of value creation. The indicator shall be calculated on the basis of enterprise's EVA. The calculating method is growth rate of EVA=[(EVA of this year-EVA of last year) $\div$ EVA of last year] $\times 100 \%$. If the value of EVA is positive, it shows that the enterprise makes real profit. The larger the growth rate of EVA is, the stronger the mature development capacity of the enterprise is; if the value of EVA is negative, it shows that the operation and management of the enterprise didn't create profits for shareholders and even brought negative effects to the enterprise and the current development capacity of the enterprise is poor. At the moment, enterprise managers should find out key factors restricting enterprise profits, 
improve management skills and perfect decisions and policies for management to realize leap-forward development.

\section{REFERENCES}

[1] Wang Zhiming. Limitations of Finance Risk Indicators and the Perfect Suggestions [J]. Manager, 2013(07):36-38(In Chinese).
[2] Jing Xin, Wang Huacheng, Liu Junyan. Science of Financial Management (Edition 6) [M].China Renmin University Press, 2010(In Chinese).

[3] Han Hongyun, He Yan. Analysis of Indicators of Enterprise Development Capacity [J]. Finance and Accounting Monthly, 2004(6):54-55(In Chinese).

[4] Li Qian. Limitations of Financial Statement Analysis and Countermeasures [J].China Township Enterprises Accounting, 2015(12):32-34(In Chinese). 